\title{
Dispersal and flight behaviour of Ips sexdentatus (Coleoptera: Scolytidae) in pine forest
}

\author{
H Jactel \\ INRA, Centre de Recherches d'Orléans, Station de Zoologie Forestière, Ardon, 45160 Olivet, France
}

(Received 30 October 1990; accepted 6 March 1991)

\begin{abstract}
Summary - The dispersal range and the flight behaviour of lps sexdentatus in pine forest were studied using mark-recapture experiments. 9614 beetles were marked by the elytra engraving method and released just after emergence. They were caught at different distances in pheromone baited traps. Less than $10 \%$ of the beetles failed to take off. Flyers were captured at distances up to $4 \mathrm{~km}$. The main dispersal occurred during the first day. When wind speed rose $>3 \mathrm{~m} / \mathrm{s}$, beetles were mainly caught in the upwind direction at the shortest trapping distances and mainly in the downwind direction at the longest trapping distances. For the same trap density, the number of beetles captured increased with trapping distance. This was interpreted as a flight exercise requisite prior to chemotropic orientation. The trapping attraction radius was estimated at $80 \mathrm{~m}$. These findings bring into question the use of the pheromone trapping system for the control and prognosis of lps sexdentatus.
\end{abstract}

Ips sexdentatus / bark beetle / pine / mark recapture / dispersal / flight behaviour / pheromone attraction

Résumé - Dispersion et comportement de vol d'Ips sexdentatus (Coleoptera: Scolytidae) en forêt de pin sylvestre. Des expériences de lâcher-recapture ont permis d'étudier la dispersion et le comportement de vol dips sexdentatus en forêt de pin sylvestre. Neuf mille six cent quatorze scolytides ont été marqués par gravage des élytres et lâchés juste après émergence. Ils ont été recapturés, à distances croissantes, par un nombre égal ou croissant de pièges à phéromone. Trois à dixhuit pour cent des scolytides se sont révélés incapables de s'envoler (tableau I). Les autres ont été recapturés jusqu'à $4 \mathrm{~km}$ du point de lâcher. Plus de $80 \%$ des captures ont été enregistrées dans les $6 \mathrm{~h}$ suivant le moment du lâcher. Pour une même densité de pièges, supposée optimale, le nombre d'insectes recapturés augmente avec la distance de piégeage (fig 2). Les scolytes ne deviendraient donc sensibles à l'attraction de la phéromone qu'après une certaine durée de vol obligatoire. Un modèle est présenté qui tient compte de ce comportement et du rayon d'action des pièges à phéromones (fig 3) pour calculer les taux de recapture en fonction de la distance de piégeage (fig 4). Le rayon d'attraction des pièges a été estimé à environ $80 \mathrm{~m}$. Ces résultats remettent en question l'utilisation de la technique de piégeage phéromonal pour le contrôle ou la prognose d'ps sexdentatus.

Ips sexdentatus / scolytide / pin sylvestre / lâcher-recapture / vol / déplacement / comportement / phéromone / piège 


\section{INTRODUCTION}

The dynamics of bark beetle populations depend largely on 2 factors: beetle population density and tree resistance (Berryman, 1972; Christiansen et al, 1987). Population density represents the effective number of insects which are able to find suitable host trees. Several authors have pointed out that, for their first flights, up to $40 \%$ mortality can occur at the insects' take off (Schmid, 1970; Schmitz, 1979; Wollerman, 1979; Shore and McLean, 1988; Salom and McLean, 1989). Because the food supply of bark beetles is often scarce, transient, and widely dispersed, beetle success may depend on flight capacity. Numerous studies suggest that flights over long distances (up to tens of $\mathrm{km}$ ) are common for many species of scolytids (Gara, 1963; Koponen, 1980; Botterweg, 1982; Nilssen, 1984). Lastly, Boren et al (1986) made a list of Scolytidae species in which flight exercise could trigger an attraction to pheromones: Dendroctonus frontalis, Dendroctonus pseudotsugae, Ips typographus, Pityogenes chalcographus, Scolytus multistriatus and Trypodendron lineatum.

Therefore, in order to understand the spatial and temporal dynamics of / sexdentatus populations, investigations into their dispersal and flight pattern become necessary. Unfortunately the literature on the dispersal of this species is very scarce (Termier, 1970; Forsse, 1989) and as yet no field experiment has been carried out. In north central France, Ips sexdentatus can produce 2 generations and numerous sister-broods (up to 7) in a year (Vallet, 1982). A flight precedes each settlement and occurs when the temperature rises to $18^{\circ} \mathrm{C}$ (Bakke, 1968; Vallet, 1982). Consequently, the flight activity of Ips sexdentatus is almost continuous from April to October.
The objectives of this study were the following: i), How far can the beetles fly, and how do wind speed and wind direction influence the orientation of the flight? ii), What is the real number of I sexdentatus which are able to fly? iii), What are the consequences of the flight behaviour on beetles response to pheromones?

\section{MATERIALS AND METHODS}

Studies employing 2 release-recapture experiments were made in the Forest of Orléans. north central France, during the summers of 1989 and 1990. They were conducted in pure stands of Scots pine, Pinus sylvestris (L), 35-75 $\mathrm{yr}$ old. When the size of an experimental plot overstepped the limits of these stands, some traps were set in mixed stands of Scots pine of the same age and Durmast oak, Quercus petraea (Mattus) Liebl. The experimental plots were chosen to be as similar as possible and with the least amount of competitive host material (logs or windfalls) which might have a strong influence on rate of beetle recapture.

All the mark-recapture experiments were set up on the same principle. Marked beetles were released in the central point of a single ring of trap locations. Several radii of trap rings (ie, minimum distances of flight) were tested, but only 1 ring was set up per plot.

Experiment 1 was designed to study the proportion of flyers and their range of dispersal. It consisted of 5 plots, at least $5 \mathrm{~km}$ apart from one another. In each plot, 4 traps were set up in a ring in 4 cardinal directions. The first plot had a radius of $50 \mathrm{~m}$, the others $100,200,500$, and $1000 \mathrm{~m}$ respectively. This experiment was replicated 3 times during the summer of 1989, but only the 3 shortest distances were tested the first time.

Experiment 2, consisting of 4 plots, was designed to investigate the need of flight exercise prior to pheromone attraction. The first plot had its traps located in a ring of $100 \mathrm{~m}$ radius, the second 200 , the third 400 and the last $600 \mathrm{~m}$. In each ring, the traps were $200 \mathrm{~m}$ apart from each other. Consequently, the 4 plots had $3,6,12$ and 18 traps respectivety, but the same number of traps per circumference section. This experi- 
ment was replicated 3 times during the summer of 1990.

In the present study, barrier-traps with flat funnels of the Röchling model were used. They were hung from support posts $1.5 \mathrm{~m}$ high. They were placed away from tree shadows and had no herbaceous plants under them. They were baited with Stenoprax ${ }^{\mathbb{B}}$ dispensers (Shell Agrar) containing the lps sexdentatus synthetic pheromone, a mixture of methyl butenol, ipsdienol and $\alpha$-pinene. This dispenser has a very short duration of efficiency (Malphettes, personal communication). Thus the traps were baited $2 \mathrm{~h}$ before the release of the beetles and the dispensers were removed on the evening of the next day. A paper saturated with lindane was put into the trap collector in order to prevent the beetles from escaping and to eliminate their predators.

The release point was set at the center of each trap ring in a sunny clearing. It consisted of a wooden platform $(17 \times 17 \mathrm{~cm})$ set into a plastic box $(25 \times 25 \mathrm{~cm})$. This box was fixed on a 1.3-m support and sheets of paper covered its base. Beetles that failed to take off from the platform fell into the box. They could then either slide over the sides of the box or swarm over the stands of the platform and try to fly again. Definitive non-flyers, which had died during release or which were unable to fly were recovered from the box.

Tested beetles were of 2 different origins. For experiment 2 and the second replication of experiment 1 , they were collected from trap trees in the Forest of Orléans just before emergence. They were held in bags containing bark and stored in a cold chamber for several weeks. For the other releases, the beetles came from laboratory breedings (Jactel and Lieutier, 1987). All the insects belonged to the second generation (offspring) except for the first replication of experiment 2, which utilised overwintering beetles. According to the literature, the response to pheromone attraction could be linked with a flight exercise. Thus, in order to compare recapture percentage, we had to use emerging beetles prior to any flight. Cold storage in a black chamber ensured lowest beetle activity between emergence and release.

Upon emergence, insects were collected and marked by the elytral engraving procedure (Lieutier et al, 1986). Because the beetles might mix their tags in the trap collector, we preferred to use the engraving method rather than fluorescent powder (Gara, 1963) or radioactive (Moore et al, 1979) marking technique. Lieutier et al (1986) reported that a slight mortality is observed with the elytra engraving method, but that the flight of surviving beetles is not affected. The beetles were marked according to their date of emergence in experiment 1 , and according to their release point in experiment 2 . The insects which emerged at a given day were distributed at random in to 4 or 5 groups, each corresponding to an experimental plot. Thus each plot received the same number of beetles of the same age and origin. Just after tagging, they were stored in damp tissues in a cold chamber for 1$10 \mathrm{~d}$ until the day of release.

On the flight day, beetles were put one by one on to the release platform when the temperature was $>20^{\circ} \mathrm{C}$. The release lasted about half an hour per plot, so total release duration was $\approx$ $3 \mathrm{~h}$, between 10 am and $1 \mathrm{pm}$. At least $3 \mathrm{~h}$ later, non-flyers were removed. Traps were checked in the late afternoon of the day of release and the following day.

In order to determine how the wind influenced the catch, data from a meteorological station were used which recorded wind speed and wind direction every $3 \mathrm{~h}$. This station was in an open field, $40 \mathrm{~km}$ from the experimental plots.

All statistical analyses were carried out using the SAS software (SAS Institute 1985).

\section{RESULTS}

\section{Experiment 1}

\section{8 marked beetles were released and} the percentage of non-flyers averaged $5.5 \%$ (table I). $81.6 \pm 7.5 \%$ of the total capture occurred on the first day and the percentage did not vary significantly between the different trapping distances $(P=0.68$, Ftest).

The percentages of recapture were significantly different between the different trapping distances $(P=0.0018, F$ test). For the 3 replications (fig 1 ), the highest recapture level was obtained at $100 \mathrm{~m}$. Despite a lower trap density, it had a significantly higher recapture level than at $50 \mathrm{~m}$. 
Table l. Percentage of non-flyers in the marked beetles released in experimented 1 and 2.

\begin{tabular}{|c|c|c|c|c|c|c|}
\hline & \multicolumn{3}{|c|}{ Experiment 1} & \multicolumn{3}{|c|}{ Experiment 2} \\
\hline & \multicolumn{3}{|c|}{ Replication } & \multicolumn{3}{|c|}{ Replication } \\
\hline & 1 & 2 & 3 & 1 & 2 & 3 \\
\hline \multirow{2}{*}{$\begin{array}{l}\text { No of beetles } \\
\text { released per plot }\end{array}$} & & & & & & \\
\hline & 661 & 369 & 430 & 400 & 255 & 254 \\
\hline$\%$ Non-flyers & $6.1 \pm 2.2$ & $3.3 \pm 1.4$ & $7.0 \pm 0.5$ & $2.9 \pm 3.2$ & $7.2 \pm 3.7$ & $18.4 \pm 4.0$ \\
\hline
\end{tabular}

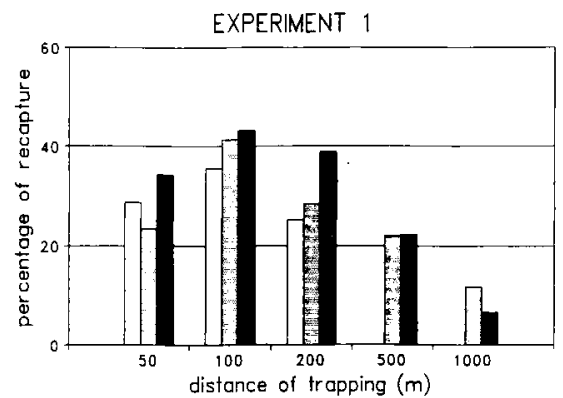

EXPERIMENT 2

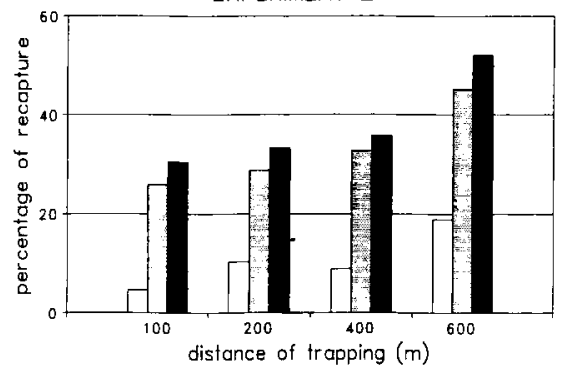

$\square$ replication $1 \square$ replication $2 \square$ replication 3

Fig 1. Percentage of recapture of the flying marked beetles according to the distance of trapping. In experiment 1 , the plots present equal numbers of traps (increasing distances between 2 nearby traps with increasing distances of trapping). In experiment 2 , the plots present equal densities of traps (same distances between 2 nearby traps with increasing distances of trapping).
Since $>80 \%$ of the capture occurred on the first day, the speed and the direction of the wind were only taken into consideration during only the first $9 \mathrm{~h}$ of the experiment to calculate the relative rate of capture in each trap of a plot, ie in each direction (fig 2). Catches were observed in all the directions, but their distribution was not uniform. Captures were more important in the upwind direction at the shortest trapping distances (50 and $100 \mathrm{~m}$ ) but more important in the downwind direction at the longest distances $(500$ and $1000 \mathrm{~m})$. This irregularity was more accurate when the wind rose $>3 \mathrm{~m} / \mathrm{s}$ (replications 1 and 3).

\section{Experiment 2}

In the 1990 experiment, the percentage of non-flyers was still low, but varied from 3$18 \%$ (table I).

The recapture rates obtained with the overwintering beetles in the first replication were consistently lower than those obtained with the offspring beetles in the last 2 replications (fig 1). The percentage of recapture increased with trapping distance. Since the experiment was conceived using a distance of $200 \mathrm{~m}$ between 2 nearby traps in all the plots; the probability of flying in a trap attraction zone was supposed 

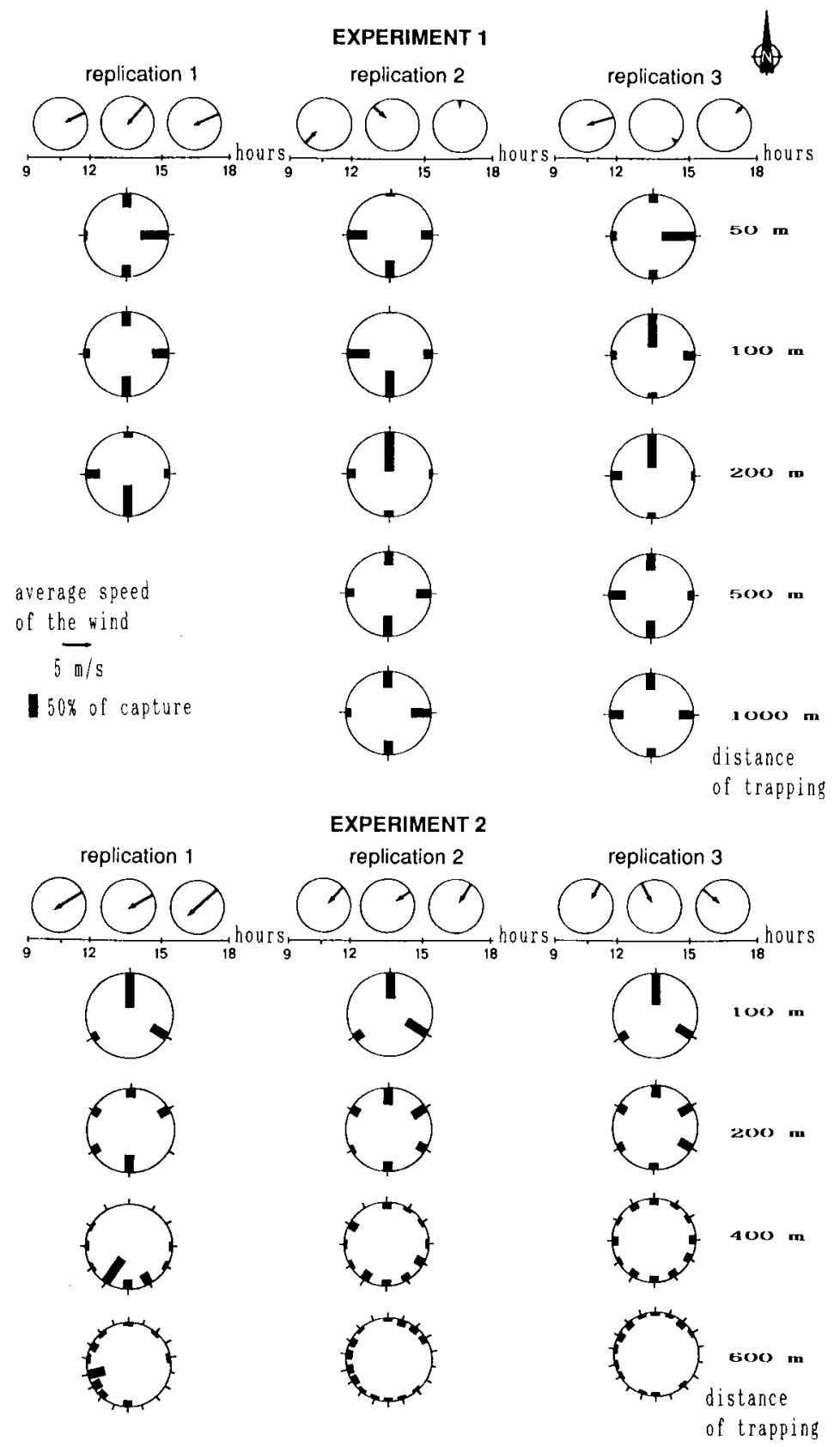

figure 2

Fig 2. Effect of wind speed and wind direction on the flight orientation of $1 p s$ sexdentatus. Relative proportions of recapture in the traps of each plot in experiments 1 and 2. 
to be equal in all the plots. Consequently, the recapture percentage would be proportional to the percentage of insects sensitive to the pheromone attraction at this distance. Thus the number of insects responsive to the pheromone attraction seemed to increase with their flight distance.

As observed in experiment 1, when the wind speed increased beyond $3 \mathrm{~m} / \mathrm{s}$ in experiment 2 (1st replication) upwind traps caught more beetles at $100 \mathrm{~m}$, whereas downwind traps caught more beetles at 400 and $600 \mathrm{~m}$ (fig 2).

\section{DISCUSSION}

\section{Non-flyers}

The percentage of I sexdentatus nonflyers was constantly low, but varied from $3-18 \%$. This variation could be linked to differences between populations since the released beetles were of several origins and since the confidence interval of each mean was narrow. Likewise, with Scolytus multistriatus, Wollerman (1979) recorded from $1-50 \%$ non-flyers for the same treatment. For Trypodendron lineatum, the proportion of non-flyers can vary from $14 \%$ (Salom and McLean, 1989) to $43 \%$ (Shore and McLean, 1988). Schmitz (1979) assumed that physiological conditions or the presence of parasites can affect flight capacity, but Forsse (1987) proved that the presence of endoparasitic nematodes does not affect the flight duration of lps typographus. In flight mill studies, an increase of the non-flyer numbers was observed as the intraspecific competition for food increased during larval development (Jactel, in preparation). These findings suggest that the non-flyer factor must be taken into account for population dynamics and thus needs more investigation.

\section{Flight distance}

The percentage of recapture was almost $10 \%$ at $1000 \mathrm{~m}$ from the release point. Twenty-four marked beetles were recovered from colleagues' pheromone traps that were $3 \mathrm{~km}$ from the present study. Moreover, as beetles were tagged according to their plot in the second experiment, it was possible to follow flights from one plot to another. Forty-six / sexdentatus were found which belonged to a different plot; this corresponded to flight distances from 1.5-4 km. Thus / sexdentatus can fly over long distances in forests like many other scolytids. According to Gara (1963) Ips confusus can fly up to $1 \mathrm{~km}$ and Dendroctonus frontalis $2 \mathrm{~km}$. Likewise Trypodendron lineatum can fly $1 \mathrm{~km}$ (Shore and McLean, 1988), and lps typographus from 20-60 km (Nilssen, 1984; Forsse and Solbreck, 1985). With such a dispersal range, bark beetles can widely explore their natural habitat. Consequently, the spatial distribution of infestation foci may radically change after each major flight.

\section{Dispersal speed}

The dispersal / sexdentatus appears to occur rapidly. Including the longest distances, almost $80 \%$ of the marked beetles were caught on the release day, ie during the $6 \mathrm{~h}$ following the first take-off. Within the same amount of time Wollerman (1979) obtained $70 \%$ of total recapture of Scolytus multistriatus and Lindelöw and Weslien (1986) and Salom and McLean (1989) found $90 \%$ respectively with Ips typographus and Trypodendron lineatum. These findings are consistent with the flight speed recorded on flight mills. All of them are almost $4 \mathrm{~km} / \mathrm{h}$ (Atkins, 1961; Gara, 1963; Jactel, 1991). This means that the dispersal of scolytids occurs over a 
short time period, thus providing more opportunity to avoid unfavorable weather and predators. The beetles caught later might have failed to take off several times (Schmid, 1970) or might have dispersed in steps.

\section{Flight behaviour}

If one assumes that the attraction zone of any trap had the same surface on the same days, we could suppose that the probability of flying into any of these zones should decrease as the trapping distance increased. Since the percentages of recapture at the trapping distance of $200 \mathrm{~m}$ were always lower than those obtained at $100 \mathrm{~m}$ in experiment 1 , we can assume that the attraction zone of the traps might have a radius of $\approx 100 \mathrm{~m}$ (if this radius were 200 $\mathrm{m}$, the decrease in the rate of recapture would have begun at $500 \mathrm{~m}$ ). Consequently, the probability of flying in 1 of the 4 zones of trap attraction would equal 1 when the beetles were released at $<100$ $m$ from the traps and would decrease for longer distances. Secondly, since the percentages of recapture were always higher at 100 than at $50 \mathrm{~m}$ in experiment 1 , we can suppose that a factor might exist which increased the probability of trapping as the distance of recapture increased. This factor could be in the form of a flight exercise requisite prior to pheromone attraction; as the trapping distance increased, the number of beetles which had performed their necessary exercise would increase, as would the attraction and rate of recapture.

The first hypothesis assumes that the attraction zone could be regarded as a disc of radius $R$ for each trap. The most widely accepted model for the pheromone dispersion in forests is the plume model (Fares et al, 1980). Taking into account this theory, the equiprobability zones of capture around a pheromone trap could be represented by concentric ellipses (McClendon et al, 1976). The long axes of these ellipses are directed with the wind and approximate discs for the highest probabilities of capture. In this study, since the percentage of recapture was the sum of the 4 traps caught in the 4 directions, the $R$ radius could have been interpreted as the average size of the capture ellipses.

The second hypothesis of the model assumed that a flight exercise might be required prior to pheromone attraction. In experiment 2 traps were placed in an order so that their attraction zones were contiguous, assuming in a first approximation that the trap attraction radius equalled $100 \mathrm{~m}$. Thus the probability of flying in an attraction zone should have tended to be $100 \%$ in all the plots. An increase of the recapture rate was found with trapping distance. If no flight exercise was necessary prior to trap attraction, we would have expected to have found the same or perhaps a decreasing percentage of recapture at the different distances due to the losses increasing as the insects keep on flying. In a laboratory experiment, Graham (1959) observed that the response behavior of Trypodendron lineatum is at first phototactic and later chemotropic only after a certain flight duration. This phenomenon was observed for many other bark beetles such as Dendroctonus pseudotsugae (Atkins, 1966; Benett and Borden, 1971), Tomicus piniperda (Perttunen et al, 1970), Scolytus multistriatus (Choudury and Kennedy, 1980), Dendroctonus frontalis (Andryszak et al, 1982) and lps typographus (Gries, 1985; Schlyter et al, 1987). Moreover, several mark-recapture procedures with concentric rings of traps obtained significant captures in the outer rings. Such is the case for Scolytus multistriatus (Lanier et al, 1976) and Trypdendron lineatum (Salom and McLean, 1989). Some authors argue that the beetles are able to respond to 
pheromone attraction as soon as they emerge (Gara and Vité, 1962; Gara, 1963; Gray et al, 1972; Lindelöw and Weslien, 1986). But this objection is not inconsistent with the main theory. It is likely that a part of the population can have a chemotropic response at the very beginning of its dispersal (Atkins, 1966; Francia and Graham, 1967; Andryzsak et al, 1982). According to the current theory, the flight threshold corresponds to the consumption of a certain part of the insect's lipid supply, which varies among the individuals in a population (Atkins, 1969; Borden et al, 1986). In a same manner, Borden (1967), Birch (1974) and Botterweg $(1982,1983)$ found overwintering beetles much less responsive to pheromones than the summer generation and attributed this to the greater lipid content in the overwintering generation (Hagen and Atkins, 1975). This could explain the lower rate of capture obtained in the first replication of the experiment 2.

According to these assumptions, a mathematical model was set up to calculate the percentage of recapture at the different distances of trapping in the first experiment. It was founded on 2 assertions:

- When $D$ (the distance of trapping) is shorter than $R \sqrt{2}$ (with $R$ the radius of the trap zone of attraction), the percentage of recapture would equal the proportion of beetles which have flown the requisite exercise (fig $3 \mathrm{a}$ ). Because this rate corresponds to a cumulative percentage of beetles, it might follow a logistic curve with the following formula:

$$
\frac{\exp (a D+b)}{1+\exp (a D+b)}
$$

- When $D$ is longer than $R \sqrt{ } 2$, the recapture percentage would be the product of the previous formula multiplied by the probability of flying in 1 of the 4 attraction zones of a plot. Each beetle was supposed to fly roughly in the same direction. Consequently its location on the plot surface might be determined by the dispersal angle in which it had flown since the takeoff (fig 3b). So, the probability of flying in a trap attraction zone would take the following form:

$$
\frac{8 \alpha}{360} \text { where } \alpha=\operatorname{arcsine}(R / D)
$$

and the rate of recapture might equal the following formula:

$$
\frac{8 \text { arcsine }(R / D)}{360} \times \frac{\exp (a D+b)}{1+\exp (a D+b)}(3)
$$

This model of 3 parameters $(a, b$ and $A)$ was fitted to the field data (fig 4) according to the NLIN procedure (SAS, 1985). It converged for a $A$ radius of $79.4 \mathrm{~m}$. This effective trapping/attraction radius multiplied by

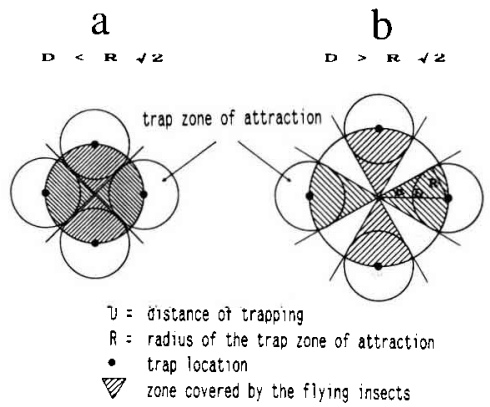

Fig 3. Schematic representation of probability of flying in a trap zone of attraction (resembling a disc) in experiment 1. a) When the trapping distance $D$ is shorter than $R \sqrt{2}$, this probability equals 1. b) When $D$ is longer than $R \sqrt{ } 2$, this probability equals $8 \alpha$ with $\alpha=\operatorname{arcsine}(R / D)$.

$$
360
$$

(the linear distance between 2 nearby traps equals $2 R \sqrt{ } 2$ ). 
percentage of recapture

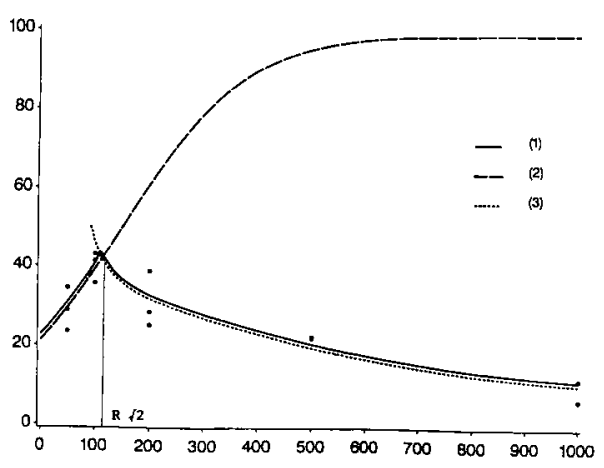

distance of trapping (m)

Fig 4. Model predicting the percentage of recapture in 4 traps according to the distance of trapping, in experiment 1. 1) Percentage of recapture of the flying marked beetles in 4 pheromone traps $(1)=(2)$ when $D<R \sqrt{ } 2 ;(1)=(3)$ when $D$ $>R$ ⒉ 2) Cumulative percentage of beetles responsive to the pheromone attraction after flight exercise. 3) Cumulative percentage of beetles responsive to the pheromone attraction multiplied by the probability of flying in a trap zone of attraction. Parameters of the model with their asymptotic $95 \%$ confidence interval: $a=0.009 \pm$ $0.006 ; b=-1.32 \pm 0.57 ; \quad A=79.4 \pm 23.9$.

$\sqrt{2}$ equals $112 \mathrm{~m}$. This value is consistent with the fact that the recapture decrease from a trapping distance of $100 \mathrm{~m}$ in experiment 1 . It is also close to the $100 \mathrm{~m}$ calculated by McClendon et al (1976) in a pheromone trapping system applied to Anthonomus grandis. Likewise Anderbrant and Schlyter (1987) indicated that the attraction range of baited sticky traps is $50 \mathrm{~m}$ or less when applied to Scolytus scolytus.

According to this model, $\approx 20 \%$ of the $l$ sexdentatus flyers were sensitive to the pheromone attraction at take-off and almost $100 \%$ after $1000 \mathrm{~m}$ of flight. These results were higher than those obtained in experiment 2. The disparity could be due to a difference between the lipid supply of the insects in 1989 and 1990. Since this disparity increased with the flight distance, it could also be due to an increasing "loss" of beetles with the distance of flight. Indeed, the number of insects attacked by predators or definitively settled on a tree should increase with the distance of flight.

\section{Influence of wind speed and wind direction}

Numerous authors have observed that scolytids first fly with the wind (Helland et al, 1984; Lindelöw and Weslien, 1986; Schlyter et al, 1987) but after a certain ammount of flight, and in the vicinity of a pheromone source, they fly upwind (Seybert and Gara, 1970; Gray et al, 1972). Choudury and Kennedy (1980) demonstrated that insects can locate an attractive source of odour by flying against an air flow in the presence of the odour. As we did in our experiments, Salom and McLean (1989) observed an inversion of the preferential directions of capture for the longest distances of trapping. These results could thus be interpreted as follows: i), in the plots with short trapping distances (50 and $100 \mathrm{~m}$ ), the beetles were already in the pheromone plume when they took off. So they flew against the wind to locate the pheromone source and they were caught preferentially in the upwind traps. This behavior is consistent with a trapping attraction radius of $79.4 \mathrm{~m}(79.4 \sqrt{2}=112 \mathrm{~m})$; ii), in the plots with long trapping distances $(400-1000 \mathrm{~m})$, the beetles took off in air with no pheromone and then flew with the wind. They were later attracted by a trap in its vicinity so the main captures were observed in the downwind direction.

We noticed such an orientation of the flight direction when the speed of the wind rose $>3 \mathrm{~m} / \mathrm{s}$. This value is more important 
than Ips sexdentatus speed of flight recorded on the flight mill (Jactel, 1991). Since we used meteorological data recorded in an open field far from the forest, we might have overestimated the real speed of the wind in the experimental plots.

\section{CONCLUSION}

Ips sexdentatus can disperse over long distances in pine forest (at least $4 \mathrm{~km}$ ). Flying with the wind, it can widely explore its habitat, searching for scarce suitable hosts. The response of I sexdentatus to pheromone attraction seems to be released by flight exercise which varies in duration among the individuals of a population. Such an internal feed-back causes the insects to move from their brood area where the food supply has been reduced. The variable threshold of response to pheromone attraction favours the interbreeding of beetles with other populations and decreases the chance of intraspecific competition for food. Flying upwind to locate the pheromone source, the beetles can benefit from a local aggregation before the mass attack of the host tree. If the orientation response is really under fueldependent flight control, the determination of the fuel content profile of a population could lead to predictions of its dispersal distribution.

In addition to the short life of the pheromone dispenser, the attraction radius of the pheromone traps does not exceed $100 \mathrm{~m}$. Since the proportion of responsive beetles does not reach $100 \%$ before at least $1000 \mathrm{~m}$, a very large number of traps would be required to intercept all the beetles of an infestation focus. Determining the number of wild beetles caught by a trap in a plot appears to be impossible. According to the flight capacity of / sexdentatus and its flight-dependent pheromone re- sponse, a trap can catch beetles coming from another plot, but inversely cannot catch all the beetles of its own plot. So, according to the dispersal range of the bark beetles, prognosis and mass-trapping could not find a reliable response in a pheromone trapping system, unless applied on a forest scale.

\section{ACKNOWLEDGMENTS}

The author thanks the Office National des Forêts for permitting him to carry out this study in the Forest of Orléans. He also thanks Mr Pidoux and Forêt-Assistance for providing the pheromone dispensers, and $F$ Lieutier for advice during the study and help in reviewing this manuscript.

\section{REFERENCES}

Anderbrant O, Schlyter F (1987) Ecology of the Dutch elm disease vectors Scolytus laevis and Scolytus scolytus (Coleoptera: Scolytidae) in Southern Sweden. J Appl Ecol 24, 539-550

Andryszak NA, Payne TL, Billings PM, Benenati JM (1982) Effect of flight activity on laboratory response of the southern pine beetle to an attractant. J Georgia Entomol Soc 17, 456460

Atkins MD (1961) A study of the flight of the Douglas fir beetle, Dendroctonus pseudotsugae Hopk (Coleoptera: Scolytidae). III. Flight capacity. Can Entomol 93, 467-474

Atkins MD (1966) Laboratory studies on the behaviour of the Douglas-fir beetle, Dendroctonus pseudotsugae Hopkins. Can Entomol 98 , 953-991

Atkins MD (1969) Lipids loss with flight in the Douglas fir beetle. Can Entomol 101, 164165

Bakke A (1968) Ecological studies on bark beetles (Coleoptera: Scolytidae) associated with Scots pine (Pinus sylvestris $L$ ) in Norway with particular reference to influence of temperature. Medd Nor Skogforsoksves 21, 443-602 
Bennett RB, Borden JH (1971) Flight arrestment of tethered Dendroctonus pseudotsugae and Tripodendron lineatum in response to olfactory stimuli. Ann Entomol Soc Am 64, 12731286

Berryman AA (1972) Resistance of conifers to invasion by bark beetle-fungus associations. Bio Sciences 22, 598-602

Birch MC (1974) Seasonal variation in pheromone-associated behaviour and physiology of Ips pini. Ann Entomol Soc Am 67, 58-60

Botterweg PF (1982) Dispersal and flight behavior of the spruce bark beetle lps typographus in relation to sex, size and fat content. $Z A n$ gew Entomol 94, 466-489

Botterweg PF (1983) The effect of attack density on size, fat content and emergence of the spruce bark beetle lps typographus $L$. $Z$ Angew Entomol 96, 47-55

Borden JH (1967) Factors influencing the response of lps confusus to male attractant. Can Entomol 99, 1164-1193

Borden JH, Hunt DWA, Miller DR, Slessor KN (1986) Orientation in forest Coleoptera: an uncertain outcome of responses by individual beetles to variable stimuli. In: Mechanisms in insect Olfaction (Payne, Birch, Kennedy, eds) Clarendon Press, Oxford

Choudury JH, Kennedy JS (1980) Light versus pheromone-bearing wind in the control of flight direction by bark beetles, Scolytus multistriatus. Physiol Entomol 5, 207-214

Christiansen E, Waring $\mathrm{RH}$, Berryman AA (1987) Resistance of conifers to bark beetle attack: searching for general relationship. For Ecol Manage 22, 89-106

Fares Y, Sharpe PJH, Magnuson CE (1980) Pheromone dispersion in forests. I Theor Biol 84, 335-359

Forsse $E$ (1987) Flight duration in lps typographus L: intensitivity to nematode infection. $J$ Appl Entomol 104, 326-328

Forsse E (1989) Flight duration of eleven species of bark beetles (Scolytidae) and observations of aerial height distribution. In: Migration of Bark Beetles with Special Reference to the Spruce Bark Beetle ips typographus. Dissertation, Sverige Lantbruksuniversitet, Uppsala

Forsse E, Solbreck Ch (1985) Migration in the bark beetle lps typographus duration, timing and height of flight. $Z$ Angew Entomol 100, 47-57

Francia FC, Giaham K (1967) Aspect of orientation behavior in the ambrosia beetle Trypodendron lineatum. Can J Zool 45, 985-1002

Gara RI (1963) Studies of the flight behavior of Ips confusus in response to attractive material. Contrib Boyce Thompson Inst 22, 51-66

Gara RI, Vité JP (1962) Studies on the flight patterns of bark beetles in second growth Ponderosa pine forest. Contrib Boyce Thompson Inst 21, 275-289

Graham K (1959) Release by flight exercise of a chemotropic response from photopositive domination in a scolytid beetle. Nature (Lond) $184,283-284$

Gray B, Billings RF, Gara RI, Johnsey RL (1987) On the emergence and initial flight behavior of the moutain pine beetle, Dendroctonus ponderosae, in eastern Washington. $Z$ Angew Entomol 71, 250-259

Gries Von G (1985) Zur Frage der Dispersion des Buchdruckers (Ips typographus L). $Z$ Angew Entomol 99, 12-20

Hagen BW, Atkins MD (1975) Between generation variability in the fat content and behavior of Ips paraconfusus. $Z$ Angew Entomol 79, 169-172

Helland IS, Hoff JM, Anderbrant O (1984) Attraction of bark beetles (Scolytidae) to a pheromone trap. J Chem Ecol 10, 723-752

Jactel $H$ (1991) A preliminary study of the dispersal potential of lps sexdentatus Boern. (Coleoptera: Scolytidae) with an automatically recording flight mill. $J$ Appl Entomol (in press)

Jactel $H$, Lieutier $F$ (1987) Effects of attack density on fecundity of the Scots pine beetle Ips sexdentatus Boern (Coleoptera: Scolytidae). $J$ App/ Entomol 104, 190-204

Koponen M (1980) Distribution of lps amitinus (Eichoff) (Coleoptera: Scolytidae) in Finland in 1974-1979. Notul Entomol 60, 223-225

Lanier GN, Silverstein RM, Peacock JW (1976) Attractant pheromone of the European elm bark beetle (Scolytus multistriatus): isolation, identification, synthesis, and utilization studies. In: Perspectives in Forest Entomology (Anderson, Kaya, eds) Academic Press, NY, 149-175 
Lieutier F (1984) Impact économique des scolytides : voies de recherches. CR Acad Agric Fr 70, 835-843

Lieutier F, Ham R, Ham M, Garcia J (1986) Une méthode de marquage individuel des coléoptères scolytides pour les études de laboratoire. Agronomie 6, 773-776

Lindelöw A, Weslien J (1986) Sex specific emergence of lps typographus (Coleoptera: Scolytidae) and flight behavior in response to pheromone sources following hibernation. Can Entomol 118, 59-67

McClendon RW, Mitchell EB, Jones JW, Mc Kinion JM, Hardee DD (1976) Computer simulation of pheromone trapping systems as applied to boll weevil population suppression: a theoretical exemple. Envir Entomol 5, 799-806

Moore GE, Taylor JF, Smith J (1979) Tracing dispersion of southern pine beetles from felled brood trees with phosphorus 32. $J$ Georgia Entomol Soc 14, 83-87

Nilssen AC (1984) Long-range aerial dispersal of bark beetles and bark weevils (Coleoptera: Scolytidae and Curculionidae) in northern Finland. Ann Entomol Fenn 50, 37-42

Perttunen V, Oksanen H, Kangas E (1970) Aspects of the external and internal factors affecting the olfactory orientation of Blastophagus piniperda. Contrib Boyce Thompson Inst 24, 293-297

Pesson P, Chararas C (1969) Les scolytides, insectes ravageurs mondiaux des forêts de conifères. Année Biol 8, 683-733

Salom SM, McLean JA (1989) Influence of wind on the spring flight of Trypodendron lineatum (Olivier) (Coleoptera: Scolytidae) in a sec- ond-growth coniferous forest. Can Entomol $121,109-119$

SAS Institute (1985) SAS User's Guide: Statistics, Version 5. SAS Institute, Cary, NC

Schlyter F, Löfqvist J, Byers JA (1987) Behavioral sequence in the attraction of the bark beethe lps typographus to pheromone source. Physiol Entomol 12, 185-196

Schmid JM (1970) Dispersal studies with radioactively tagged spruce beetles. USDA For Ser Rocky Mountain For and Range Exp Stat Res Note RM 178

Schmitz RF (1980) Dispersal of pine engraver beetles in second growth Ponderosa pine forest. In: Proc 2nd IUFRO Conf, Dispersal of Forest insects (Berryman, Safranyik, eds) 41-50

Seybert JP, Gara RI (1970) Notes on flight and host selection of the pine engraver lps pini. Ann Entomol Soc Am 63, 347-350

Shore TL, McLean JA (1988) The use of markrecapture to evaluate a pheromone-based mass trapping program for ambrosia beetles in a sawmill. Can J For Res 18, 1113-1117

Termier M (1970) Essai d'interprétation du vol des Coléoptères. CR Acad Sci Paris 270 , $1157-1160$

Vallet E (1982) Données bio-écologiques récentes sur trois insectes ravageurs responsables du dépérissement du pin sylvestre en région centre: Tomicus piniperda, Ips acuminatus et lps sexdentatus. Bull Inst Ecol App/9, 3-41

Wollerman EH (1979) Attraction of European elm bark beetles, Scolytus multistriatus, to pheromone-baited traps. J Chem Ecol 5, $781-793$ 